\title{
METODE FLEKSIBILITAS GURU-GURU PESANTREN DARUD DAKWAH WAL-IRSYAD MANGKOSO DALAM MENCEGAH FAHAM RADIKALISME
}

\author{
Muhsin \\ Moch. Qasim Mathar \\ Mahmuddin
}

\begin{abstract}
Abstrak: Tulisan ini mengkaji tentang fleksibilitas guru-guru dalam mencegah faham radikalisme dan sekularisme di kalangan santri Pondok Pesantren DDI Mangkoso Barru. Penelitian ini bersifat deskriptif kualitatif yang dilaksanakan pada Pondok Pesantren DDI Mangkoso Barru. Pendekatan yang digunakan adalah pendekatan multi disipliner yang mencakup pendekatan spiritual, psikologis, pedagogis, yuridis, fenomenologis, dan historis. Sumber data dalam penelitian ini adalah pimpinan pondok pesantren, kepala kampus, wakil kepala kampus, kepala madrasah, wakil kepala madrasah, guru akidah akhlak, pembina asrama, profil pesantren, data tenaga pendidik dan kependidikan serta data santri. Metode pengumpulan data yang digunakan pada penelitian ini adalah observasi, wawancara, dan dokumentasi. Instrumen penelitian adalah peneliti sendiri sebagai key instrumen, artinya peneliti sendiri sebagai instrumen kunci dan penelitian disesuaikan dengan metode yang digunakan. Penulis menggunakan satu jenis instrumen yaitu; "Pedoman Wawancara". Pengolahan dan analisis data mengikuti teori Miles dan Huberman, melalui tiga tahap, yaitu reduksi data, penyajian data (display data) dan verifikasi data atau penarikan kesimpulan. Pengecekan keabsahan data yang digunakan dalam penelitian ini ada tiga macam, yaitu triangulasi sumber, triangulasi teknik, dan triangulasi waktu. Hasil penelitian ini menunjukkan bahwa fleksibilitas guru-guru pondok pesantren DDI Mangkoso pada dasarnya mendukung semua asumsi dasar dari faham konstruktivisme. Yang menjadi alatnya atau media untuk mengaplikasikan teori fleksibilitas, agar bisa memberikan pengalaman realistis yang berbeda dan otentik kepada setiap individu dalam menangkal faham radikalisme dikalangan santri pesantren DDI Mangkoso, yang peniliti temukan di lapangan adalah guru-guru pondok pesantren DDI Mangkoso dalam melaksanakan kegiatan pembelajaran, ilmu-ilmu ushul yang menjadi kompotensi utama diajarkan.
\end{abstract}

Keywords: Radikalisme, Pesantren, Fleksibilitas 


\section{PENDAHULUAN}

Sejak terjadinya serangan peristiwa peledakan bom di beberapa tempat di Indonesia. Khususnya di Bali (12 Oktober 2002 dan 1 Oktober 2005), di Hotel JW. Marriott Jakarta (5 Agustus 2003), dan di Kedutaan Besar Australia di Kuningan Jakarta (9 September 2004), citra pesantren menjadi tercoreng. Lembaga pendidikan tertua di Indonesia ini dituduh sebagai bagian dari kelompok Islam radikal dan sarang teroris. Alasannya, karena sebagian pelaku peledakan bom tersebut diduga kuat- sebagian telah divonis bersalah oleh pengadilan-adalah orang-orang pesantren. Sebut saja misalnya; Ustadz Abu Bakar Ba'asyir, adalah pengasuh Pondok Pesantren al-Mukmin, Ngeruki, Sukoharjo, Surokarta, Jawa Tengah; Amrozi, Ali Imran, Mukhlas, dan Imam Samudra, adalah alumni pesantren al-Mukmin Ngeruki. Amrozi dan adiknya, Ali Imron, juga merupakan adik kandung Ustadz Khozin, pendiri dan pengasuh Pondok Pesantren al-Islam, Tenggulun, Solokuro, Lamongan, Jawa Timur. Karena itu, kedua pesantren tersebut pernah masuk catatan hitam aparat yang harus diawasi aktivitasnya, bahkan pernah digrebek dan digeledah. ${ }^{1}$

Tapi, benarkah tuduhan bahwa pesantren merupakan sarang teroris dan bagian dari kelompok Islam radikal? Cukupkah alasan, hanya dengan menyebut Ustadz Abu Bakar Ba'asyir, Amrozi, Imam Samudra, dan kawan-kawan, untuk memvonis pesantren sebagai sarang teroris? Tentu saja tidak cukup. Kasus yang menimpa beberapa orang pesantren tidak bisa digeneralisasikan untuk semua pesantren, perlu kajian mendalam terhadap keberadaan pesantren, terutama tradisi pesantren DDI Mangkoso sejak berdirinya tahun 1938 silam, merupakan soko guru pencetakan ulama di Sulawesi Selatan, pendirinya adalah al-Magfurullah AG.H. Abd. Rahman Ambo Dalle, sekaligus beliau dikenal Ulama dari tanah Bugis. Dari segi Anggaran Dasar DDI dipertegas, bahwa DDI adalah berasaskan Pancasila dan berhaluan Ahlu Sunnah wal Jama'ah.

Eksistensi dan peran pesantren, sebenarnya tidak bisa dipisahkan dari organisasi terbesar di negeri ini, yaitu Nahdlatul Ulama (NU) yang memiliki paling banyak pesantren di tanah air. KH. Shalahuddin Wahid dalam makalahnya"Pokok-Pokok Pikiran Tentang NU Masa Depan" yang dipaparkan dalam acara serasehan Nasional pra muktamar NU ke XXXII di Cianjur yang dihelat PP ISNU pada 13 Maret 2010, menjelaskan, untuk memahami pesantren di Indonesia tidak bisa dilepaskan NU, karena untuk memahami NU seorang harus paham tentang 4 hal, di antaranya; pertama ajaran ahlusunnah wal jama'ah, meliputi kehidupan bermasyarakat (ukhuwah, tasamuh, tawassuth, dan tawazun). dalam menjalankan kehidupan bermasyrakat NU bisa menjadi garda terdepan dalam membangun persaudaraan dengan mengambil prinsip ukhuwahnya, membangun toleransi antar ummat beragama dengan mengambil perinsip tawassuth dan tawazun. jika pesantren di Indonesia ini mengambil perinsip sebagaimana perinsip yang dijalankan NU, DDI, Muhammadiyah, dan masih ada lagi organisasi keislaman lainnya. Maka toleransi antarummat beragama akan bisa terbangun dengan baik dan tidak ada lagi kekerasan yang dilatarbelakangi agama.

${ }^{1}$ Lihat Mohammad Kosim, Pesantren dan Wacana Radikalisme, h. 42-43 
Dapat dipahami bahwa metode fleksibilitas dalam penelitian ini difokuskan pada pembelajaran yang berdomain kompleks dan tidak terstruktur dengan baik. Dengan fleksibilitas kognitif, berarti kemampuan untuk menyusun secara sepontan suatu pengetahuan, dalam banyak cara, dalam memberi respon penyesuaikan diri untuk secara radikal merubah tuntutan (situasional). ${ }^{2}$ Dengan metode flesibilitas menunjukkan kecakapan pendidik di dalam mengelola dan membimbing, mengarahkan, memotivasi, dan menyiapkan kondisi-kondisi tertentu, sehingga materi pendidikan dapat diterima peserta didik dengan mudah. Efeknya, dapat mempermudah peserta didik untuk mencapai tujuan pendidikan. Dapat dikatakan pula, bahwa metode flesibilitas merupakan upaya pendidik untuk memperjelas jalan yang akan ditempuh peserta didik di dalam mewujudkan kebenaran. ${ }^{3}$ Ketepatan dalam menggunakan metode fleksibilitas, akan mengakibatkan kerja pendidik lebih efisien dan efektif.

Dalam melakukan proses kegiatan pembelajaran korikuler maupun ekstra korikuler di upayakan pendekatan kontekstual tanpa menghilangkan substansi tekstual, karena pada gilirannya santri akan terjun di masyarakat untuk menjawab segala persoalan antar masyarakat yang plural dengan agama dan negara dalam konteksnya sendiri.

Penulis telah mengamati munculnya faham radikal di Indonesia dewasa ini, karena negara memberikan kebebasan untuk beragama. Oleh karena itu, peneliti sangat tidak setuju dengan pemahaman tersebut (radikal). Jika pemahaman ini dibiarkan berkembang, maka negara Indonesia akan semakin galau. Oleh sebab itu, kegalauan dapat teratasi dengan pendekatan kontekstual dan intertekstual, dapat diukur pada seberapa banyak menerapkan metode fleksibilitas.

Metode fleksibilitas sangat diperlukan terhadap semua tenaga pendidik dan kependidikan, karena terkait dengan tantangan global. Peneliti melihat dan mengamati pada lembaga pendidikan pesantren khususnya pesantren DDI Mangkoso, dapat dilihat mulai dari pimpinan sampai tenaga pendidik dan kependidikannya, kurikulum pengajarannya sangat mengutamakan metode fleksibilitas. Salah satu bukti sejarah pendiri utama (KH. Abd. Rahman Ambo Dalle) dimasa kepemimpinannya selalu bermitra dengan pemerintah. Karena keberadaan pesantren memiliki peranan penting dalam menentukan arah pembangunan bangsa ke depan. Betapa tidak, lembaga itu telah dianggap singkron dengan kultur masyarakat.

Problematika kehidupan manusia sulit mendapatkan solusi jika syariat Islam belum dijalankan dengan benar, karena manusia dengan syariat Islam adalah paket keselamatan dan kebahagiaan hidup yang Allah telah berikan kepada hamba-Nya. Ketika manusia menyadari sebagai makhluk, maka secara spontan tunduk dan patuh terhadap syariat Allah swt.

Ajaran Islam mencakup secara keseluruhan yakni segala aspek kehidupan manusia lahir batin dalam istilah (rahmatan lil alamin). Radikal dalam pengamatan peneliti adalah sekelompok manusia yang ingin menghancurkan Islam dari dalam. Dalam rangka melakukan pencegahan, diharapkan

\footnotetext{
${ }^{2}$ (http.//www.phoenix.scl.fct.unl.pt),(imposio). Tanggal 22 Maret 2018.

${ }^{3}$ Lihat Suroso Abdussalam, Sistem Pendidikan Islam (Cet. I; Bekasi Barat: Sukses Publishing, 2011), h. 82.
} 
menggunakan berbagai macam metode, agar tidak terjadi resistensi di kalangan ummat islam, diantaranya adalah menggunakan metode flesibilitas di kalangan muballig maupun di kalangan tenaga pendidik dan tenaga kependidikan disetiap lembaga pendidikan.

Pondok pesantren DDI Mangkoso, telah dan sedang berupaya untuk selalu mencegah faham radikalisme sejak dari tahun 1938 sampai sekarang. Salah satu bukti, AG.al-Magfurullah H. Abd. Rahman Ambo Dalle pendiri utama Pesantren DDI Mangkoso, dimasa hidup beliau masuk menjadi anggota partai golongan karya, karena partai tersebut adalah kendaraan pemerintah orde baru pada masanya. Sikap yang dilakukan AG Al-Magfurullah H.Abd. Rahman Ambo Dalle menurut analisa peneliti, itu merupakan salah satu upaya agar pemerintah tidak beranggapan bahwa Organisasi dan Lembaga Pendidikan Pesantren yang beliau dirikan bukan ladang radikalisme tetapi ladang rahmat Allah swt.

Untuk tujuan itu dikembangkan kurikulum dan suasana belajar tertentu (kurang lebih sama dengan pondok pesantren masa kini). Dari pendekatan itulah lahir guru-guru dan ulama yang berkrakter. Mereka dibawa atau dikirim ke berbagai daerah, mendampingi, menjadi guru, dan bersama masyarakat membangun sekolah-sekolah DDI. Salah satu yang khas dari gerakan itu, selain kurikulumnya, adalah sekolah-sekolah DDI itu menyatu dengan masyarakat setempat. Dari satu sisi, DDI bisa disebut sebagai sekolah masyarakat. Dengan cara seperti itu, pada masanya, DDI dikenal dan menjadi salah satu pilar pendidikan di Indonesia. DDI turut memberikan sumbangsi dalam membangun karakter dan mencerdaskan anak bangsa. ${ }^{4}$

Peneliti juga telah mengamati secara pedagogi, guru-guru pesantren DDI Mangkoso cukup fleksibel dalam mendidik para santrinya agar terhindar dari faham radikal. guru-guru pesantren DDI Mangkoso tetap konsisten dengan mabda' DDI, yakni berinteraksi sesama indiviu dengan individu-individu lainnya berdasarkan faham ahlu al-Sunnah wal-Jama'ah berhaluan moderat. Dengan demikian, tentu menjadi penting untuk dilakukan penelitian mengenai fleksibilitas guru-guru pesantren DDI Mangkoso dalam upaya mencegah faham radikalisme. Walaupun telah banyak penelitian tentang radikal, namun penelitian ini lebih spesifik pada pencegahannya.

\section{FLEKSIBILITAS DALAM MENCEGAH FAHAM RADIKALISME 1) Pengertian Fleksibilitas}

Teori tentang fleksibilitas yang dianggap relevan dalam penelitian tesis ini adalah Cognitif Fleksibility. Artinya kemampuan seseorang untuk membiasakan strategi proses pengetahuan ke hal yang baru dalam kondisi yang tidak diharapkan di lingkungan, atau sebuah kemampuan yang dapat mempengaruhi secara tidak langsung proses pembelajaran, ini diperoleh dengan pengalaman, meliputi proses adaptasi dari proses kognisi. Sebuah strategi dalam konteks definisi ini, adalah sebuah rangkaian operasi pencarian masalah. Karena itu, kognitif fleksibiliti menunjukkan perubahan perilaku yang kompleks. ${ }^{5}$

\footnotetext{
${ }^{4}$ Lihat AG. H. Ali Yafie, Peran Ulama DDI Dalam Dinamika Kemajemukan dan Kemoderenan, (Jakarta: Taushiyah, Tudang sipulung Nasional, 2014), h. 4.

${ }^{5}$ (http://tip.psyc hology.org/spiro.html). tanggal 22 Maret 2018.
} 
Gagne memandang strategi kognitif sebagai representasi dari fungsi kontrol dalam memproses informasi, dan menyusun apa yang orang biasa namakan sebagai pengetahuan kondisional. Misalnya, peserta didik menggunakan strategi kognitif untuk mengontrol perhatian mereka, menolong diri mereka dalam menyerap informasi baru, dan untuk memperbaiki keberhasilan merek dalam mengingat informasi penting pada saat melakukan tes dalam ujian tertentu. ${ }^{6}$

Fleksibilitas kognitif ini termasuk kemampuan untuk menghadirkan kembali pengetahuan dan perpektif kasus dan konsep yang berbeda. dan pada saat diperlukan dapat mengkonstruksikan konsep dan kasus tersebut untuk memahami suatu hal atau memecahkan suatu masalah. Menurut teori fleksibilitas kognitif siswa sendiri pada saat mereka mempelajari, menyimpan serta membentuk struktur pengetahuan mereka. Hal ini sangat relevan dengan teori konstruktivisme. Fleksibilitas kognitif membutuhkan pembelajaran yang fleksibel informasi harus bisa disajikan dalam berbagai cara dan bisa digunakan untuk berbagai keperluan. Pada bagian lain dikatakan sasaran dan pembelajaran berbeda untuk tingkat awal dan pembelajaran lanjut. Pada pembelajaran tingkat awal, guru sering puas jika muridnya dapat menunjukkan konsep yang dangkal, seperti yang ditunjukkan oleh hasil tes yang diwajibkan kepada siswa hanya untuk mengingat kembali apa yang telah diajarkan secara garis besar. Jika materi yang disajikan adalah materi yang terstruktur dengan baik, atau mengandung materi yang kompleks yang sifatnya liner menjadi tidak efektif. ${ }^{7}$

Melalui pendekatan metode fleksibilitas, diharapkan dapat mengantisipasi kelemahan-kelemahan sistem pendidikan madrasah dan pesantren saat ini, kelemahan tersebut juga dialami oleh sistem pendidikan umum di Indonesia. Terlebih dalam rangka menanggulangi faham radikalisme, kelemahan-kelemahan tersebut menurut Mastuhu adalah: 1. Mementingkan materi di atas metodologi; 2. Mementingkan memori di atas analisis dan dialog; 3. Mementingkan pikiran vertikal/linier di atas lateral; 4. Mementingkan penguatan pada 'otak kiri' di atas 'otak kanan'; 5. Materi pelajaran agama yang diberikan masih bersifat tradisional, belum menyentuh asfek rasional; 6. Penekanan yang berlebihan pada ilmu sebagai produk final, bukan pada proses metodologinya; dan 7. Mementingkan orientasi 'memiliki' di atas 'menjadi'.

Dalam mengantisipasi kelemahan-kelemahan kondisi ril madrasah dan pesantren yang dapat memicu munculnya faham radikalisme, menurut $\mathrm{M}$. Haberman dan Stennett yang dikutip dari Harbert La Grone (1964) pada garis besarnya ada 5 daerah pengetahuan yang perluh dikuasai dengan baik oleh setiap calon guru, yaitu:

a. Studi analisis terhadap pengajaran. Terdiri dari bentuk-bentuk intraksi verbal dan nonverbal, konsep penelitian dan pengajaran, kelas sebagai sistem sosial emosional dan hakikat kepemimpinan (leadership).

${ }^{6}$ Lihat Muhammad Yaumi, Prinsip-Prinsip Desain Pembelajaran (Cet. I; Jakarta. PT. Fajar Interpratama Mandiri, 2013), h. 104.

${ }^{7}$ (http://tip.psychology.org/spiro.html). diakses pada tanggal 22 Maret 2018.

${ }^{8}$ Lihat, Mujamil Qamar, Menggagas Pendidikan Islam (Cet. I; Bandung: PT. Remaja Rosdakarya, 2014). h. 96. 
b. Struktur dan kegunaan pengetahuan. Siswa diharapkan menguasai pengertianpengertian dasar yang berhubungan dengan hakekat dan kegunaan pengetahuan dan bagaimana struktur itu mempengaruhi seni mengajar.

c. Konsep-konsep tentang perkembangan manusia dan belajar. Aspek-aspek ini meliputi pengetahuan tentang struktur intelek, pertumbuhan kognitif, tipe-tipe belajar, dan konsep-konsep dasar misalnya motivasi dan kesiapan.

d. Desain belajar mengajar. Ini berhubungan dengan metode, siswa (calon guru) diharapkan mempelajari cara-cara menentukan tujuan, menggunakan strategi, mengembangkan unit-unit belajar, serta menggunakan sistem-sistem instruksional dan pengajaran berprogram.

e. Demonstrasi dan evaluasi kompetensi-kompetensi mengajar. Studi ini meliputi pengalaman-pengalaman percobaan mengajar. Menganalisis kompetensi yang didemonstrasikan. Dan masalah-masalah profesinal lainnya. ${ }^{9}$

Metode instruksional yang fleksibel adalah metode yang dapat membantu siswa untuk mempelajari kontur dan kompleksitas material yang di pelajari. Selain itu juga harus mampu membantu siswa untuk bekerja dengan menggabungkan dari beberapa perspektif yang berbeda. Spiro mencontohkan pembelajaran dan pelatihan yang berkaitan dengan materi yang kompleks, tidak terstruktur, yang harus diperlakukan secara berbeda dengan domain pengetahuan yang relatif sederhana. Spiro mencontohkan domain yang tidak terstruktur dengan baik misalnya, sejarah, pengobatan, hukum, interpretasi, literatur, serta pendidikan guru dan sebagainya. Pendekatan pembelajaran untuk tingkat pemula akan menjadi tidak efektif jika di terapkan untuk transfer pengetahuan tingkat yang lebih tinggi (higher level transfer skill) pada saat orang pertama kali mempelajari sesuatu, maka dia akan memisahkan dan mengkategorikan pengetahuannya ke dalam slot-slot tertentu. Tetapi pada saat mulai belajar lebih lanjut dan mulai menggunakan pengetahuannya untuk memecahkan masalah, maka pembelajaran harus memiliki fokus pada fresentasi informasi yang beragam. Materi bisa saja di cakup beberapa kali untuk kebutuhan yang berbeda. ${ }^{10}$

Penulis menilai bahwa domain radikalisme, merupakan domain yang tidak terstruktur dengan baik atau konpleks maka teori fleksibilitas kognitif yang lebih efektif untuk diterapkan. Dengan teori tersebut, guru seharusnya mengetahui karakterstik peserta didik, dengan memahami bahwa semua orang dilahirkan dengan bentuk muka dan warna kulit yang berbeda-beda sekalipun anak yang dilahirkan kembar. Dalam bahasa agama, perbedaan ini merupakan anugrah Ilahi yang harus disyukuri karena menyimpan suatu kekuatan jika mampu dikelola dengan benar. Namun, menjadi masalah jika tidak dapat diorganisasi dengan baik. Mengelola perbedaan bukan berarti memberikan ruang yang sebebas-bebasnya untuk mengembangkan perbedaan tanpa disertai dengan pencarian persamaan, tetapi mengelola perbedaan artinya menggali dan mengidentifikasi berbagai keunikan masing-masing, kemudian dibagi dan disalurkan sehingga terjadi interaksi yang saling membutuhkan antara satu dengan lainnya. Keunuikan tersebut terdiri atas keunikan yang bersifat umum atau disebut dengan

${ }^{9}$ Lihat Oemar Hamalik, Pendidikan Guru Berdasarkan Pendekatan Kompetensi (Cet. VII; Jakarta: PT. Bumi Aksara, 2010), h. 105

${ }^{10}$ (http://tip.psyc hology.org/spiro.html). tanggal 22 Maret 2018. 
karakteristis umum dan keunikan khusus disebut dengan karakteristis khusus. Dapat dicontohkan yang bersifat umum seperti perbedaan budaya, suku, agama, gender, dan latar belakang status sosial sangat berguna dalam mendesain pelajaran, begitu pula karakteristik khusus seperti perbedaan gaya belajar, kecerdasan, termasuk lingkungan belajar membawa dampak tersendiri dalam proses pembelajaran. ${ }^{11}$

\section{2.) Fleksibilitas Guru-Guru Mencegah Faham Radikalisme}

a. Penguatan pemahaman ilmu-ilmu Ushul di kalangan santri, antara lain:

1) Qawa'id al- Fiqhiyah

Dalam mempelajari ilmu ini, santri dapat mengetahui metodologi memahami ilmu syari'ah sekaligus mengintrepertasi dalil-dalil nash al-Qur'an maupun al-Sunnah misalnya:

a) Qaidah "La dhararah wala dhirarah" mengandung pengertian bahwa syari'at itu tidak susah dan tidak menyusahkan. contoh sebagai berikut:

1) Tidak boleh seorang tetangga semau-maunya mengeluarkan aroma yang tidak sedap dari rumahnya, tanpa sepengetahuan dengan tetangganya.

2) Tidak boleh seseorang melarang seseorang pengendara melewati jalan umum, jika sipengendara memenuhi semua kwajibankewajibannya untuk melewati jalan tersebut.

3) Tidak boleh seorang pedagang, menjual barang dagangannya bila ada cacatnya tanpa memberitahukan kepada si calon pembeli.

b) Qaidah "al-Dhararu Yazalu” mengandung pengertian, menghilangkan yang menyususahan, dapat di contohkan sebagai berikut:

1) Jika seseorang mau menyelesaikan kasus yang menimpanya, maka dia harus mengajukan ke pengadilan, maka seorang hakim berkewajiban mengadilinya untuk menyelesaikan kasus hukum yang menimpanya.

2) Bagi seseorang menderita suatu penyakit, maka diupayakan agar mencari fasilitator yang membuat penyakitnya sembuh, dan selamat dari penyakit yang dideritanya, dan membantu orang agar selamat dari kesusahan itu adalah mendekatkan diri kepada ketakwaan.

3) Bagi kaum muslimin ketika menyaksikan becana, maka harus membantu orang yang sedang ditimpa bencana tersebut, dalam rangka penyelamatan. ${ }^{12}$

\section{2) Ushul al-Fiqh}

Dalam rangka penguatan ilmu-ilmu pokok kepada santri, maka pelajaran Ushul al-Fiqh merupakan kompetensi pokok utuk membentuk jati dirinya membuat metodologi penerapan hukum-hukum syari'ah ketika terjun di masyarakat, tentunya kompetensi ini pula diharapkan santri terhindar dari

\footnotetext{
${ }^{11}$ Lihat Muahammad Yaumi, Prinsip-Prinsip Desain Pembelajaran, h. 118.

${ }^{12}$ Lihat Muhammad Bakri Ismail, al-Qawa'id al-Fiqhiyah, (Cet. I: Kairo; Dar al-Manar, 1997), h. 96-99.
} 
paham radikalisme. Seperti yang dijelaskan oleh Syek Abu Zahrah dalam kitab ushul al-Fiqhnya, penjelsan tentang "al-Haram" sebagai berikut: sudah tidak diragukan lagi bahwa semua yang diharamkan syari'ah pasti mendatangkan bahaya. Dan semua yang dibolehkan pasti mendatangkan manfa'at. Lebih lanjut Syekh Abu Zahrah membagi haram secara garis basar menjadi dua bagian yaitu; 1. Haram Zat (obyek), sperti: Bangkai, minuman khamar, berzinah, mencuri, berjudi, dan sebagainya. 2. Haram selain zatnya (sebab akibat), seperti: memandang aurat perempuan, menjadi pemicu terjadinya perzinahan. Transaksi yang mengandung unsur riba, membuat seseorang mengkonsumsi riba, sedangkan riba termasuk haram zat. Dalam menyikapi persolan haram, syekh Abu Zahrah kembali mempertegas bahwa persoalan haram menurut syari'ah adalah agar manusia terpelihara pada lima hal, yaitu: Terpelihara jiwa; Terpelihara keturunan; Terpelihara harta; Terpelihara akal; dan Terpelihara agama. ${ }^{13}$

Dalam pandangan al-Syaikh Muhammad bin al-Syaukany, dalam kitabnya Irsyad al-Fuhul, persoalan “Kontradiksi Masalah Larangan”. Beliau memberi penjelasan, bahwa larangan itu terbagi pada dua bentuk, yaitu:

a) Larangan harus disertai keterangan.

Dalam artian semua peristiwa hukum, yang diselesaikan melalui proses pengadilan, antara yang tergugat dengan penggugat maka kedua belah pihak harus mampu memberi penjelasan ketika dituntut untuk memberi keterangan.

b) Larangan tanpa keterangan.

Larangan seperti ini, mengandung arti bilamana larangan tersebut sudah jelas, maka larangan tersebut sudah tidak butuh lagi keterangan, sebaliknya jika tidak maka harus dijelaskan dengan sempurna. Misalnya larangan yang diberlakukan disuatu negara, tapi tidak di negara lain. ${ }^{14}$ Maka harus dijelaskan dengan sempurna. ${ }^{15}$

3) Ushul al-Tafsir.

Ushul Tafsir merupakan ilmu alat yang diajarkan di pesantren DDI Mangkoso, dalam rangka memenuhi kebutuhan santri untuk tidak mudah terjebak dalam faham radikalisme, karena dalam ilmu ini diajarkan metodologi memahami refrensi dalam memahami penafsiran ayat-ayat alQur'an, sejalan dengan itu metodologinya adalah: a) Penafsiran ayat dengan ayat; b) Hadis Nabi menjelaskan al-Qur'an; c) Qaul Sahabah menafsirkan kandungan ayat; dan d) Qaul Tabi'in.

4) Ushul al-Hadis

Dalam upaya mencegah faham radikalisme di kalangan santri pondok pesantren DDI Mangkoso, peneliti menilai bahwa membekali santri ilmu

\footnotetext{
${ }^{13}$ Lihat Muhammad Abu Zahrah, Ushul al-Fiqh, (Mesir, Dar al-Fiqr al-Araby, 1958), h. 43.

${ }^{14}$ Seperti larangan bagi non muslim masuk di tanah haram, tapi tidak diberlakukan diluar batas tanah haram, begitu juga di Indonesia bilamana ada perempuan hamil diluar nikah, maka tidak ada pasal dalam KUHP untuk wajib menikahi sipelaku, yang ada hanya hukum kurungan.

${ }^{15}$ Lihat Muhammad Ali al-Syaukany, Irsyad al-Fuhul (Cet. I; Bairut: Dar Ibnu Katsir, 2000), h. 757.
} 
ushul al-Hadis merupakan hal yang sangat urgen. Hal ini dimaksudkan agar santri dapat menidentifikasi hadis yang dapat diterima menjadi sumber hukum dan hadis mana yang tidak bisa, Adapun yang dapat diterima adalah hadis sahih dan hadis hasan.

Demikian juga santri seyogyanya dilengkapi pengetahuan tentang hadis-hadis yang tertolak, tujuannya adalah agar santri mempunya kemampuan untuk menentukan hadis mana yang bisa dijadikan sebagai dasar hukum, dan hadis mana yang tidak.

\section{III.METODOLOGI PENELITIAN}

Penelitian ini bersifat deskriptif kualitatif yang dilaksanakan pada Pondok Pesantren DDI Mangkoso Barru. Pendekatan yang digunakan adalah pendekatan multi disipliner yang mencakup pendekatan spiritual, psikologis, pedagogis, yuridis, fenomenologis, dan historis. Sumber data dalam penelitian ini adalah pimpinan pondok pesantren, kepala kampus, wakil kepala kampus, kepala madrasah, wakil kepala madrasah, guru akidah akhlak, pembina asrama, profil pesantren, data tenaga pendidik dan kependidikan serta data santri. Metode pengumpulan data yang digunakan pada penelitian ini adalah observasi, wawancara, dan dokumentasi. Instrumen penelitian adalah peneliti sendiri sebagai key instrumen, artinya peneliti sendiri sebagai instrumen kunci dan penelitian disesuaikan dengan metode yang digunakan. Penulis menggunakan satu jenis instrumen yaitu; "Pedoman Wawancara". Pengolahan dan analisis data mengikuti teori Miles dan Huberman, melalui tiga tahap, yaitu reduksi data, penyajian data (display data) dan verifikasi data atau penarikan kesimpulan. Pengecekan keabsahan data yang digunakan dalam penelitian ini ada tiga macam, yaitu triangulasi sumber, triangulasi teknik, dan triangulasi waktu.

\section{HASIL PENELITIAN DAN PEMBAHASAN}

Berbicara tentang fleksibilitas guru-guru Pondok Pesantren DDI Mangkoso terhadap faham radikalisme. Peneliti melakukan wawancara dengan pimpinan pada Pondok Pesantren DDI Mangkoso Barru, yakni AG. H. M. Faried Wadjedy, MA. mengatakan;

Pimpinan Pondok Pesantren DDI Mangkoso, melihat dan mengamati keadaan negara saat sekarang ini sangat memprihatinkan karena banyaknya aliran-aliran yang berkembang. Namun kami di Pondok Pesantren DDI Mangkoso, Alhamdulillah berhaluan ahlussunnah waljama'ah wasyatiyah. Karena ada yang berhaluan ahlussunnah waljama'ah yang ekstrim (keras), saya melihat dan mengamati bahwa mereka memahami dalil-dalil dari al-Qur'an dan al-Hadis hanya secara harfiah atau teks semata-mata, tidak memperhatikan keadaaan atau kondisi di sekitarnya. Kemudian saya dan para guru-guru Pondok 
Pesantren DDI Mangkoso, Alhamdulillah fleksibel maksudnya toleransi dalam fur'iyah dan bersatu dalam akidah. ${ }^{16}$

Mengamati dan menganalisis wawancara di atas, bahwa Pimpinan Pondok Pesantren DDI Mangkoso, memang istiqamah dan teguh pendirian, sehingga guru-guru segan dan sangat hormat kepada pimpinan. Kemudian peneliti juga sering mengikuti ceramahnya disuatu pengajian di Masjid bahwa terkait persoalan sunnah-sunnah, kita harus toleransi tidak boleh dijadikan permasalahan apalagi berbeda faham, dalam sebuah kaidah ushul fiqhi mengatakan; "Janganlah engkau perselisihkan atau perdebatkan hal-hal yang fur'iyah (cabang). Dan sesungguhnya yang perlu diperselisihkan/diperdebatkan adalah hal-hal yang pokok.

Dalam ajaran agama Islam telah diketahui bahwa ada ajaran pokok dan ada ajaran sunnah. Maka dari itu, ajaran pokok adalah harga mati dan semua ulama ahlussunnah sepakat tidak ada perselisihan, berbeda dengan ajaran-ajaran sunnah. Peneliti melakukan wawancara dengan AG. H. M. Faried Wadjedy, MA, tentang ajaran-ajaran sunnah dikalangan ahlussunnah waljama'ah, beliau mengatakan;

Saya melihat dan mengamati di kalangan ahlussunna wal-jama'ah terbagi tiga pemahamannya dalam memahami dalil dari al-Qur'an maupun alHadis yaitu; (1) ekstrim kanan maksudnya mereka memahami ayat dan hadis secara tekstual atau dapat dikatakan radikal. (2) moderat adalah faham ahlussunnah wal-jama'ah wasyatiyah. ${ }^{17}$

Peneliti mengamati wawancara di atas, tampaknya pimpinan Pondok Pesantren DDI Mangkoso Barru berada pada ahlussunnah wal-jama'ah wasyatiyah (moderat). Namun saat sekarang ini ada beberapa alumni dari Mangkoso ada yang masuk kelompok radikalisme bahkan masuk kelompok syi'ah tersesat, lalu bagaimana tanggapan Pimpinan Pondok Pesantren DDI Mangkoso. Oleh sebab itu, peneliti melakukan kembali wawancara dengan AG. H.M. Faried Wadjedy, MA. Dalam wawancara tersebut beliau mengatakan:

Tidaklah adanya seperti itu, lalu seenaknya mau menuduh bahwa Pesantren DDI Mangkoso berfaham radikalisme. Kalau mau objektif, langsung saja lihat dan amati pimpinannya. Sejak saya kembali dari Cairo Mesir, telah banyak yang mengintai saya dari pihak kepolisian atau aparat keamanan di masa orde baru, bahwa bagaimana dengan modelnya orang ini dari Timur Tengah. Karena pada saat itu, Iulusan Timur Tengah dicurigai sebagai kader-kader untuk melahirkan "Komando Jihad" informasi pada saat itu adalah isu-isu yang diangkat oleh Beni Murdani dari Arab Saudi. Kemudian pada saat orde baru berkuasa, saya pernah ditawari masuk partai Golkar dan disedorkan formulir, lalu saya menandatangi formulir tersebut, bukan pada tempat tanda tangan tetapi

\footnotetext{
${ }^{16}$ AG.H.M. Faried Wadjedy, Pimpinan Pondok Pesantren DDI Mangkoso, Wawancara, tanggal 05 Juli 2016.

${ }^{17}$ AG.H.M. Faried Wadjedy, Pimpinan Pondok Pesantren DDI Mangkoso, Wawancara, tanggal 05 Juli 2016.
} 
di sampingnya. Apa maksudnya? Yaitu saya bukan Golkar tetapi saya adalah pendukung Golkar. ${ }^{18}$

Mengamati dari wawancara di atas, pimpinan Pondok Pesantren DDI Mangkoso, tampak jelas moderat dan netral tidak memihak. Pemimpin yang seperti ini sangat diharapkan untuk dapat memersatukan umat Islam. Substansi keberadaan DDI adalah memersatukan umat dengan istilah Darud Da'wah walIrsyad artinya membuat suatu tempat atau wadah untuk mengajak umat menuju ke jalan yang lurus. Selanjutnya, peneliti kembali melakukan wawancara tentang bagaimana bentuk fleksibilitas guru-guru Pondok Pesantren DDI Mangkoso dalam mencegah faham radikalisme, dengan kepala Madrasah Aliyah Putra DDI Mangkoso, yakni Ust. Abd. Gaffar, MA mengatakan:

Bentuk fleksibilitas guru-guru terhadap faham radikalisme, sesuai dengan apa yang telah dikemukakan Pimpinan Pondok Pesantren DDI Mangkoso bahwa kita lebih baik berada pada posisi wasyatiyah (moderat) karena implementasi dari rahmatan lil alamin itu ada pada faham moderat. ${ }^{19}$

Peneliti mengamati dan menghayati wawancara tersebut di atas, bahwa memang pilihan yang terbaik dalam memahami agama Islam adalah faham moderat, karena Islam adalah agama rahmatan lil alamin artinya Islam merupakan agama yang membawa rahmat dan kesejahteraan bagi semua manusia, bahkan alam semesta beserta isinya (semua makhlul Allah yang ada di darat, di laut dan di udara).

Islam melarang manusia berlaku semena-mena terhadap makhluk Allah swt, sungguh begitu indahnya Islam. Maka dari itu, faham radikalisme sangat bertentangan dengan ayat $\mathrm{di}$ atas. Lalu, upaya dalam mencegah faham radikalisme, hal yang paling utama dapat dilakukan adalah memperkenalkan ilmu pengetahuan agama Islam dengan baik dan benar. Kemudian meminimalisir kesenjangan sosial, menjaga persatuan dan kesatuan diantara sesama manusia, karena telah dipahami bahwa dalam sebuah masyarakat pasti terdapat keberagaman atau kemajemukan.

Peneliti melakukan wawancara dengan Ust. Dr. H. Muh. Aydi Syam, Pembina Pondok Pesantren DDI Mangkoso, tentang dugaan dari masyarakat bahwa pondok pesantren itu, adalah wadah radilkalisme, lalu bagaimana tindakan bapak jika ada guru pondok pesantren DDI Mangkoso yang berfaham radikalisme? Ust. Dr. H. Muh. Aydi Syam, mengatakan;

${ }^{18}$ AG.H.M. Faried Wadjedy, Pimpinan Pondok Pesantren DDI Mangkoso, Wawancara, tanggal 05 Juli 2016. Juni 2016.

${ }^{19}$ Abd. Gaffar, Kepala Madrsah Aliyah Putra DDI Mangkoso, Wawancara, tanggal 29 
Alhamdulillah selama ini tidak pernah terjadi di kalangan para guru-guru pesantren, karena guru-guru pesantren pada umumnya adalah alumni kita sendiri. Sejak awal berdirinya pondok pesantren ini diajarkan bahwa Islam yang wasyatiyah (moderat) dan toleransi sangat dijunjung tinggi, karena itulah prinsip pondok pesantren DDI Mangkoso, ada somboyannya mengatakan; "Bersatu dalam akidah dan toleransi dalam fur'iyah". 20

Maka dalam masalah fur'iyah ini sering terjadi ijtihad dalam mengistinbatkan hukumnya. Dari sinilah sering terjadi perbedaan pendapat di antara para ulama dan mujtahid. Jadi dalam masalah furu' yang ijtihadi ini hendaknya setiap muslim bersifat saling bertoleransi yaitu mengikuti mana yang dianggap paling baik di antara pendapat-pendapat yang ada, tidak memaksa orang lain mengiktui pendapatnya dan membiarkan tidak mencelah orang lain yang tidak sependapat. Oleh karena itu, sikap toleransi perlu ditumbuhkan, karena hidup di kalangan masyarakat yang beragam dan majemuk. Toleransi adalah sikap menghargai dan menghormati perbedaan antara sesama manusia. Allah swt, menciptakan manusia berbeda satu sama lain. Perbedaan tersebut bisa menjadi kekuatan jika dipandang secara positif. Sebaliknya, perbedaan bisa memicu komplik jika dipandang secara negatif.

Sebagai ilustrasi, jika kita memperhatikan salah satu unsur bangunan, misalnya tembok, maka tembok itu berdiri beberapa bagian yakni batu bata, besi, semen dan pasir. Jika masing-masing bagian itu berdiri sendiri tanpa ada persatuan dan keterkaitan maka tidak akan mempunyai kekuatan. Setelah bagianbagian itu dipersatukan dicampur dengan air, disusun rapi, maka ia menjadi satu bangunan yang kokoh. Ini semua menggambarkan bahwa perbedaan merupakan sumber kekuatan apabila bersatu dan bekerjasama. Oleh karena itu Islam mengajarkan untuk menghargai dan menghormati perbedaan. Toleransi dalam Islam mencakup dua hal; yakni toleransi antar sesama muslim dan toleransi kepada non muslim. Toleransi sesama muslim berarti menghargai dan menghormati perbedaan pendapat yang ada dalam ajaran Islam. misalnya, perbedaan pendapat mengenai jumlah rakaat salat tarwih. Perbedaan dalam tubuh agama Islam masih bisa toleransi apabila terjadi dalam masalah fur'iyah (cabang), seperti jumlah rakaat tarwih, do'a qunut dan lain-lain. Namun kita tidak boleh toleransi dalam masalah ushul (pokok) dalam Islam, misalnya kitab suci alQur'an, kiblat dan Nabi. Ada orang mengaku Islam tetapi kiblat salatnya bukan di ka'bah, kitab sucinya bukan al-Qur'an, nabinya bukan Muhammad saw. Maka kita harus menolak keras pendapat seperti itu, namun tidak boleh berbuat anarkis atau menghakimi sendiri dengan tindakan kekerasan.

Salah satu contoh yang dibuktikan umat Islam di Indonesia pada tanggal 2 Desember 2016 yakni aksi damai 212 sangat luar biasa damainya, padahal yang dipersoalkan adalah masalah pokok, karena ada oknum nonmuslim (Ahok) mantan Gubernur Jakarta menistakan al-Qur'an. Tetapi umat Islam seindonesia menolak keras penistaan tersebut namun tidak anarkis, itulah salah satu gambaran bahwa Islam adalah rahmatan lil alamin. Toleransi merupakan salah satu akhlak

${ }^{20}$ H. Muh. Aydi Syam, Pembina Pondok Pesantren DDI Mangkoso, Wawancara, tanggal 10 Juli 2016. 
mulia yang harus dimiliki setiap muslim. Dengan menjunjung tinggi sikap menghargai perbedaan ini maka kehidupan masyarakat akan damai dan sejahtera.

Oleh karena itu, kita harus menerapkan toleransi dalam kehidupan seharihari baik di lingkungan sekolah, rumah, maupun masyarakat. Dalam kehidupan sehari-hari toleransi dapat diwujudkan dengan sikap-sikap sebagai berikut:

1. Bergaul dengan semua teman tanpa membedakan agamanya.

2. Menghargai dan menghormati perayaan hari besar keagamaan umat lain.

3. Tidak menghina dan menjelek-jelekkan ajaran agama lain.

4. Memberikan kesempatan kepada teman nonmuslim untuk berdo'a sesuai agamanya masing-masing.

5. Memberikan kesempatan untuk melaksanakan ibadah bagi nonmuslim. Memberikan rasa aman kepada umat lain yang sedang beribadah.

6. Tidak memaksakan kehendak kepada orang lain.

7. Mengadakan silaturrahim dengan tetangga yang berbeda agama.

8. Menolong tetangga beda agama yang sedang kesusahan.

Selanjutnya, peneliti melakukan wawancara tentang bagaimana bentuk fleksibilitas guru-guru Pondok Pesantren DDI Mangkoso dalam mencegah faham radikalisme dengan wakil kepala Madrasah Aliyah Putra DDI Mangkoso yakni Drs. H. Muh. Asy'ari mengatakam:

Silahkan lihat dan amati langsung guru-guru pesantren DDI Mangkoso, dalam bentuk sikap, pergaulan, tutur katanya. Alhamdulillah selama ini tidak pernah terjadi faham radikal, karena memang tidak pernah diajarkan faham tersebut, hanya selalu dikatakan bahwa marilah kita menjadi manusia yang terbaik. Karena manusia yang terbaik adalah manusia yang selalu bermanfaat kepada sesamanya. ${ }^{21}$

Peneliti mengamati wawancara di atas bahwa manusia yang terbaik adalah manusia yang selalu bermanfaat kepada sesamanya. Oleh karena itu, marilah kita menjadi manusia yang selalu bermanfaat kepada sesama. Maka dari itu, manusia yang terbaik ada pada faham moderat, dan tentu tidak dijumpai pada faham radikalisme. Dengan demikian faham radikalisme sangat bertentangan dengan ajaran Islam, karena Islam sebagai rahmatan lil alamin yakni menaungi alam semesta beserta isinya. Rahmatan lil alamin yang peneliti pahami adalah menjaga ketenangan, kedamaian, ketenteraman dan tidak saling mengganggu di antara sesama makhluk ciptaan. Oleh sebab itu, perlu diajarkan kepada santri tentang kitab-kitab yang bisa mengantar pada maksud dan substansi dari pada rahmatan lil alamin, lalu peneliti melakukan wawancara tentang kitab-kitab yang diajarkan kepada santri agar mereka tidak berfaham radikal dan yakni H. Muh. Asy'ari mengatakan:

Kitab-kitab yang diajarkan di Pondok Pesantren DDI Mangkoso telah diseleksi oleh pimpinan pondok pesantren (AG. Prof. Dr. H. M. Faried Wadjedy, MA), beliau sangat hati-hati terhadap kitab-kitab yang di ajarkan pada santrinya, alhamdulillah selama ini yang diajarkan kepada

${ }^{21}$ H.Muh. Asy'ari, Wakil Kepala Madrasah Aliyah Putra DDI Mangkoso, Wawancara, tanggal 30 Juni 2016. 
santri mulai dari tingkatan Ibtidaiyah sampai pada perguruan tinggi yakni bernuansa ahlussunnah waljama'ah yang moderat. ${ }^{22}$

Peneliti mengamati dari wawancara di atas yakni ahlussunnah waljama'ah yang moderat, tentu ada ahlussunnah wal jama'ah yang lain kalau begitu, maka peneliti semakin bingun dan penasaran dalam hal ahlussunnah wal jama'ah, maka dari itu peneliti kembali melakukan wawancara tentang faham ahlussunna wal wajama'ah yang moderat dengan pembina Pondok Pesantren DDI Mangkoso yakni Drs. H. Muh. Ansar Taha, MA, mengatakan;

Ahlussunnah artinya berpegang pada sunnah kemudian jama'ah artinya sahabat. Namun saya melihat dan mengamati sekarang tampaknya ahlusunnah wal jama'ah terbagi tiga yakni ekstrem kanan, ekstrem kiri dan moderat. Adapun yang ekstrem kanan yaitu kecenderungannya dalam memahami dalil hanya secara harfiah, kemudian yang ekstrem kiri yaitu kecenderungannya serba boleh atau liberal, lalu kami di Pondok Pesantren DDI Mangkoso, alhamdulillah ahlussunnah wasyatiyah (moderat) dan itulah sebagai penjabaran rahmatan lil alamin yang saya pahami. ${ }^{23}$

Dari wawancara di atas, peneliti mengamati dan menghubungkan dengan keadaan dewasa ini, memang tampak jelas bahwa umat Islam di Indonesia terkotak-kotak, sehingga pemahaman agama Islam juga demikian. Maka dari itu peneliti berasumsi, seandainya para elit politik Islam di Indonesia bisa menyatukan faham yang moderat, maka peneliti yakin negara akan aman, damai, tenteram dan makmur. Faham moderat selalu menghindarkan perilaku atau pengungkapan yang ekstrem, bahkan kecenderungannya pada demensi jalan tengah dan pandangannya cukup ia mau mempertimbangkan pandangan pihak lain. Peneliti sepertinya kebingungan melihat situasi dan keadaan dewasa ini, kenapa umat Islam pemahamannya ada yang ekstrem kanan dan ada yang ekstrem kiri, maksudnya ada yang terlalu keras dan ada yang terlalu longgar atau liberal. Padahal kalau kita membaca sejarah Islam di masa Nabi Muhammad saw, tidak ada yang seperti itu.

Zaman globalisasi, corak keberislaman yang baik adalah menjadi Muslim yang moderat. Istilah moderat ini dimunculkan dan dipopulerkan oleh berbagai kalangan baik cendikiawan, penceramah, mahasiswa muslim atau berbagai kalangan. Memang pada awal kemunculannya istilah ini banyak dipakai oleh pihak yang mengajak kepada pemahaman Islam yang progressif, aktual dan tidak ketinggalan zaman sehingga lewat bibir merekalah kata ini menjadi tren baru dalam tradisi keislaman. Pemahaman moderat (wasatiyah) adalah salah satu karakteristik Islam yang tidak dimiliki oleh ideologi-ideologi lain.

${ }^{22}$ H.Muh. Asy'ari, Wakil Kepala Madrasah Aliyah Putra DDI Mangkoso, Wawancara, tanggal 30 Juni 2016.

${ }^{23}$ H. Muh. Ansar Taha, Pembina Pondok Pesantren DDI Mangkoso, Wawancara, tanggal 11 Juli 2016. 
Ada falsafah lain memandang bahwa sikap wasatiyah Islam adalah salah satu sikap penolakan terhadap ekstremitas dalam bentuk kezaliman dan kebatilan, ia tidak lain merupakan cerminan dari fitra asli manusia yang suci yang belum tercemar dari pengaruh-pengaruh negatif. Dan untuk menghindari pengaruhpengaruh negatif tentu ada upaya. Salah satu upayanya yakni mengisi waktu kosong dengan kegiatan positif, misalnya melakukan kegiatan yang mempererat ukhuwah Islamiah kepada sesama manusia dan saling tolong menolong dalam kebaikan.

Islam sangat menganjurkan saling tolong menolong di antara sesama manusia. Dengan saling menolong akan dapat meberikan keringanan di antara satu dengan yang lain. Selain itu, manfaat lain dari saling tolong menolong juga dapat mempererat kasih sayang di antara sesama, mampu menciptakan sikap rasa saling hormat menghormati saling menghargai dalam kehidupan bermasyarakat di antara individu. Dengan demikian tampak kehidupan bermasyarakat aman damai tenteram, dan itulah ajaran Islam yang sesungguhnya. Selain dari itu keutuhan umat manusia akan terbangun dengan kuat, sesuai dengan tujuan Bhinneka Tunggal Ika.

\section{KESIMPULAN}

Berdasarkan pada pembahasan yang telah dipaparkan sebelumnya maka peneliti mengemukakan kesimpulan bahwa fleksibilitas guru-guru pondok pesantren DDI Mangkoso pada dasarnya mendukung semua asumsi dasar dari faham konstruktivisme. Yang menjadi alatnya atau media untuk mengaplikasikan teori fleksibilitas, agar bisa memberikan pengalaman realistis yang berbeda dan otentik kepada setiap individu dalam menangkal faham radikalisme dikalangan santri pesantren DDI Mangkoso, yang peniliti temukan di lapangan adalah guruguru pondok pesantren DDI Mangkoso dalam melaksanakan kegiatan pembelajaran, ilmu-ilmu ashul yang menjadi kompotensi utama diajarkan. 


\section{DAFTAR PUSTAKA}

Abdussalam, Suroso, Sistem Pendidikan Islam, Cet. I; Bekasi Barat: Sukses Publishing, 2011.

Hamalik, Oemar, Pendidikan Guru Berdasarkan Pendekatan Kompetensi Cet. VII; Jakarta: PT. Bumi Aksara, 2010.

Ismail, Muhammad Bakri, al-Qawa'id al-Fiqhiyah, Cet. I: Kairo; Dar al-Manar, 1997.

Mohammad Kosim, Pesantren dan Wacana Radikalisme

Qamar, Mujamil, Menggagas Pendidikan Islam Cet. I; Bandung: PT. Remaja Rosdakarya, 2014.

Syaukany, Muhammad Ali al-, Irsyad al-Fuhul Cet. I; Bairut: Dar Ibnu Katsir, 2000.

Yafie, AG. H. Ali, Peran Ulama DDI Dalam Dinamika Kemajemukan dan Kemoderenan, Jakarta: Taushiyah, Tudang Sipulung Nasional, 2014.

Yaumi, Muhammad, Prinsip-Prinsip Desain Pembelajaran, Cet. I; Jakarta. PT. Fajar Interpratama Mandiri, 2013.

Zahrah, Muhammad Abu, Ushul al-Fiqh, Mesir, Dar al-Fiqr al-Araby, 1958.

(http.//www.phoenix.scl.fct.unl.pt),(imposio). tanggal 22 Maret 2018.

(http://tip.psyc hology.org/spiro.html). tanggal. 22 Maret 2018.

(http://tip.psychology.org/spiro.html). diakses pada tanggal 22 Maret 2018.

(http://tip.psyc hology.org/spiro.html). tanggal 22 Maret 2018. 